\title{
Critical analysis of marketing in Croatian publishing
}

\author{
Silvija Gašparić1, Gorana Petković', Suzana Pasanec Preprotić1 \\ 'University of Zagreb, Faculty of Graphic Arts, Getaldiceva 2, 10000 Zagreb \\ E-mail: gasparic.silvija@gmail.com, gorana.petkovic@grf.hr, spasanec@grf.hr
}

\begin{abstract}
Marketing is an inevitable part of today's modern lifestyle. The role that marketing plays is so big that it has become the most important part of business. Due to crisis that is still affecting publishers in Croatia, this paper emphasizes the power of advertising as a key ingredient in how to overcome this situation and upgrade the system of publishing in Croatia. The framework of the paper is based on marketing as a tool that leads to popularization of books and sales increase. Beside the experimental part which gives an insight into public's opinion about books, publishing and marketing, the first chapter gives the literature review and analysis conducted on the whole process of book publishing in Croatia with pointing out mistakes that Croatian publishers make. Also, benefits of foreign publishing will be mentioned and used for comparison and projection on to the problems of the native market. The aim of this analysis and this viewpoint paper is to contribute the comprehension of marketing strategies and activities and its use and gains in Croatian publishing.
\end{abstract}

Keywords: publishing, marketing, marketing strategies, marketing activities, book promotion

\section{Introduction}

The discovery of printing press, gunpowder and compass are rated as the most revolutionary inventions in the humankind history. With Gutenberg's first printed book in $15^{\text {th }}$ century, the first step to information flow, education and literacy was made. Trough $19^{\text {th }}$ century the publishing industry thrived and new technologies for paper production and printing production were developed. With the economy and export growth, books were published in tens of thousands copies and more. After 1950s, with invention of automated book binding, soft book covers and cheaper paper, publishing editions reached over 50000 copies per book. The choice of books to read became unlimited, and books became a product for massive use [1]. The purpose of book is to spread culture, information, knowledge and thoughts. In one way it is a work of art, changing through the ages, reflecting the time it is written in and making it part of history forever; but it is also a piece of paper bind with covers into a final product. Book, and thus publishing, has two functions: the culture function and an economy function.

If definition of publishing is simplified, publishing is selling books. Publishing as an activity preserves existing cultural values but it also fulfils them. Although the term publishing includes many different types of products (newspaper, e-books, music, blogs, video games, etc.), this paper deals only with books as publishing products, which when they are placed on the market in the purpose of selling, have 
to speak to the buyer [2]. The data has shown a decline trend in registry of book publishing firms in Croatia. Croatia's publishing is still in a crisis and has difficulties coming out of it. An independent survey that was conducted by the GfK agency in March 2017 has shown that only $53 \%$ of Croatian population have read at least one book per year. On the other hand, countries like German (68\%), France (67\%) and Italy $(75 \%)$ have higher percentage than Croatia in a survey conducted on the reading at least one book per month [3]. To make the market more optimal for publishing industry, marketing needs to be explored from every angle - from understanding the needs of potential buyers, distribution, promotion (online and offline) to outside circumstance and many other marketing elements.

\subsection{Literature review of basic marketing terms in publishing}

\subsubsection{Business plan}

The first step of making business plans is research. Marketing research needs to start the very moment that the idea for a book has been made. With a research, the book gains a targeted audience, an understanding of the needs that will be satisfied with this book and its benefits or flaws in comparison with other competitive similar books [4]. It is a process of systematic design, collection of data, analysis, evaluation and information reports of data relevant for marketing situation in which the publishing house is; all with a goal of better connecting the supply of the publisher and demand of the market.

A complete business plan includes strategical, publishing and marketing plan. To make a strategic plan means to set a short-sighted and long-sighted goals and a very strict direction that leads to wanted business results. To combine vision, strategy and objective is to get a strategical plan that can face any industrial and competitive terms, that can predict moves of key rivals and possible problems and challenges that presents an obstacle to company's success [5]. Publishing plan is a plan of book titles that will be published through the year. With the title of the book, it has to be a plan regarding the size of edition, and of course the date schedule for each book launch. According to the publishing plan, a concept of expenses and incomes are made and for those purposes, every publishing department needs to participate so a synergy between market needs and publisher's resources is made. Marketing plan works on two levels - tactical level and strategical level. Strategical marketing plan determines the targeted audience and market, and an offer of values represented to them, all based on the analysis of best marketing opportunities. Tactical plan of marketing decides specific tactics; like product characteristics, promotion, sales, price and distribution channels [6].

\subsubsection{Integrated marketing communication}

Integrated marketing communication is a process that starts with a potential buyer and uses all forms of communication wanting to create synergistic influence that can influence buyer's behaviour and create a long-term relation.

The most important part of integrated marketing communication in publishing is a promotion plexus and online marketing. Promotions are variables of marketing plexus used for providing information about new book titles, sales activities and campaigns to targeted groups of people. Promoted book can be the biggest title of the year and can have the power to enhance people's lives, but in order to do that, potential buyers need to know about it [7]. Advertising, sales improvement, personal selling, public relations and direct marketing are all part of promotion plexus. Advertising is a mass communication form that refers to publications (newspapers, magazines), radio, television and other media (internet, billboards, cinema, etc.); everything that has direct communication oriented to the buyer and whose time and place of promotion have to be paid for [8]. Public relations is a mass communication form, which builds mutually beneficial contacts and relations between an organization and its public. The most popular form of this communication is placing the news trough editors and newspapers. Editors estimate the value of the information given and publish it according to that. As for the sales improvement, the typical examples are coupons, prize games, gifts that come with a book and are related to it, signing authors, stickers and similar events. It is a temporary 
event organized for enhancing the chances of sale of particular product and services [7].

Online promotions are the fastest growing part of direct marketing. Society today is maximally computerized, and the internet has open many opportunities to new models of marketing. Online marketing is every marketing activity that needs some kind of interactive technology. Online marketing can be used for exploring the market, because a large capacity of internet servers that store and allow analysing different kinds of data. The best example for direct online book marketing is Amazon. Amazon began as the largest library in the world and is now the largest online shop in the world. Furthermore, today's lifestyle dictates a frequent use of Facebook, LinkedIn, Twitter and many other networks that puts everybody in an interaction with a lot of people. Costumer to costumer model of marketing and social networks that support it has become the most powerful tool in online marketing business practice. Network word of mouth (WOM) started as an accidental and uncontrollable thing, but today it is planned and directed. It allows customers to be marketing experts, to evaluate the products, to comment, to evaluate the services and to leave a great impact on further sales [9].

Another powerful tool of online marketing is RSS or Really Simple Syndication. It is a connection between targeted buyers and content producer; a tool that helps promote a new book to the buyers by sending an RSS feed - information about new titles directly after an update on the web page. Also, there is a service called Google AdWords which makes advertising more individual and cheaper, based on an advertising related to typed keywords.

\subsubsection{Sale-distribution marketing activity}

The main task of sales manager is to hire capable people who will with training, motivation, grading and planning acquire strategic and tactical skills that will give the firm competitive advantage. Ability to influence the buyers is often the key difference and what ensures the purchase [10].

The main goal of sale-distribution activities is to reduce expenses. Research has shown that more options and the bigger books offer leads to more insecure buyer and to fewer purchases
[11]. By reducing the offer, reducing expenses is inevitable and there are few easy ways to do that. For example, number of book stores can be reduced at the expense of those who have low monthly incomes. Sometimes, the bestplaced book stores does not have enough copies of bestseller in the sale days, and in other places, bestsellers are left unsold. Also, it is very important to reduce a number of book titles in 'lower price' promotions and avoid parallel 'lower cost' promotions in one place. One of solutions for reducing expanses can be reducing delivery options and number of possibilities to order [12]. Further, sales and distribution must work together to insure buyer's supply in the right time at the right place in a convenient assortment [13]. Book stores are crucial in publishing business and publishers should be more aggressive when it comes to direct sales, because it has the highest income and has benefits like creating a database of buyers that leads to long-term relations. One of overlooked marketing channels are kiosks and supermarkets. For example, on the first day of the release, Harry Potter and the Deathly Hallows were sold in 2.7 million copies, and 500000 copies were sold in a supermarket chain called Asda [14]. Another important term related to sale-distribution marketing activities is 'print on demand' which made a switch from traditional model of 'print then sale' to a modern model of 'sale then print' which lowers the risks of creating stockpiles, lowers operating tasks and expenses of stocking and distributing. This model made a lot of things possible, like bringing to life old sold out books, allowing sales of second hand books, bringing possibility for self-publishing, ability to personalize books as a marketing tool for attracting customers, making books available worldwide and creating a whole new market for networked costumers and a source of incomes for publishers like Amazon [15, 16].

\section{Experimental part}

By literature review and analyse of existing research data, it was possible to prove theoretical views from the first chapter, but also to define new issues required for the implementation in this research and critical analysis of marketing in Croatian publishing. 


\subsection{Analysis of existing research data}

Existing research data are mainly referred to the most frequently used marketing concepts and marketing activities in the publishing industry. According to Blažević, $67 \%$ of Croatian publishers do not use advertising. Modern media is more popular than traditional advertising, and $83 \%$ do not use TV, $67 \%$ do not use radio and 53\% do not use advertising in publications. Internet advertising use $57 \%$ of publishers and $70 \%$ of them use social media too. $70 \%$ of publishers use public relations as a free-form of promotion [12]. Globally, modern media advertising is also more popular, and $66 \%$ of publishers use online promotions [17]. Most publishers have a web sites and profiles on social networks, but most of them think that online marketing does not affect incomes significantly. $80 \%$ of publishers in Croatia use social networks (mainly Facebook) for placing the information about new books, $47 \%$ for prized games and only $30 \%$ for research of users' needs. They hardly use RSS (only 10\%) or Google AdWords (only $27 \%$ ) as marketing tools, and $47 \%$ do not use direct marketing [12]. Publishers in Croatia should follow Amazon example when it comes to online book stores. Amazon has an option of subscribing, so customers can save a little bit of money and use a free two days delivery if they are Amazon Prime subscribers. This business model is great for attracting profitable buyers because subscribe price is high enough to drive away less profitable customers, but also not so high for a loyal buyer that buys a lot [18]. This model will not take a place in Croatia book publishing yet, because according to GfK, book stores are dominant sale channel and 50\% of sales are made in book stores. Second best are small shops like kiosks [3].

\subsection{Methodology}

To prove arguments that were made throughout previous chapters, but also to explore new issues relevant for this critical review, a survey was conducted on a large number of respondents. The goal of this survey was to determinate a public opinion on a topic of publishing in Croatia and their aspect on the importance of reading culture.

\subsubsection{Survey concept and data collection}

For data collection and analysis, web survey was used. Survey contained three groups of questions. First group of general questions was related to respondents' gender, age and education level. Second group had five simple 'yes or no' questions related to their habits, preferences and reading culture in Croatia (Table 1). In last group, with six questions, respondents evaluated marketing quality of publishers in Croatia and offered marketing activities (Figure 1-3, 5, $7-8$ ). For this group of questions, psychometric Likert rating scale was used. This scale of agreement or disagreement, on a symmetric scale for series of statements, was used to capture intensity of respondents' feelings and their opinions.

\subsubsection{Respondents}

The number of respondents was 200. All 200 surveys were validly filled because it was a closed type questionnaire and all questions were mandatory. More respondents were women $(89.2 \%)$ and they belong into a category of younger population ageing from 19 to 35 (94\%). Most of them have a high school degree (56.6\%), bachelor's degree have $16.9 \%$ and master's degree $18.7 \%$. Elementary school degree have only $6 \%$ and doctoral degree only $2.4 \%$.

\section{Research results}

In following table (Table 1), results of second group of survey questions are presented. Furthermore, following figures (Figures 1-3, 5, 7-8) are presenting respondents' answers and opinion about the main aim of this article research - marketing in Croatian publishing.

Table 1. Results of 'yes or no' group of questions related to respondents' reading culture

\begin{tabular}{|l|c|c|}
\hline QUESTION & YES & NO \\
\hline Do you often read? & $74.1 \%$ & $25.9 \%$ \\
\hline Do you read books in English? & $37.3 \%$ & $62.7 \%$ \\
\hline $\begin{array}{l}\text { Do you order books from Amazon, or } \\
\text { another web shop? }\end{array}$ & $6 \%$ & $94 \%$ \\
\hline $\begin{array}{l}\text { Do you think Croatia needs an online } \\
\text { web shop library like Amazon? }\end{array}$ & $80.4 \%$ & $19.6 \%$ \\
\hline $\begin{array}{l}\text { Would you order and read more } \\
\text { if more titles were translated in } \\
\text { Croatian language? }\end{array}$ & $76.1 \%$ & $23.9 \%$ \\
\hline
\end{tabular}




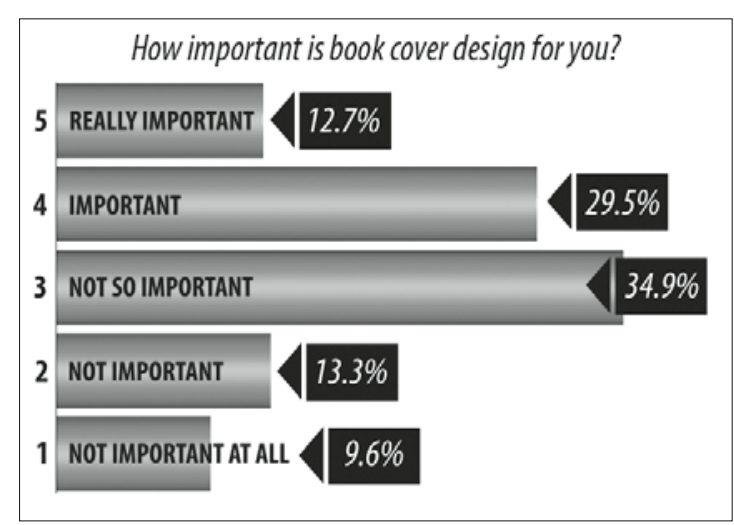

Figure 1. Importance of book cover design

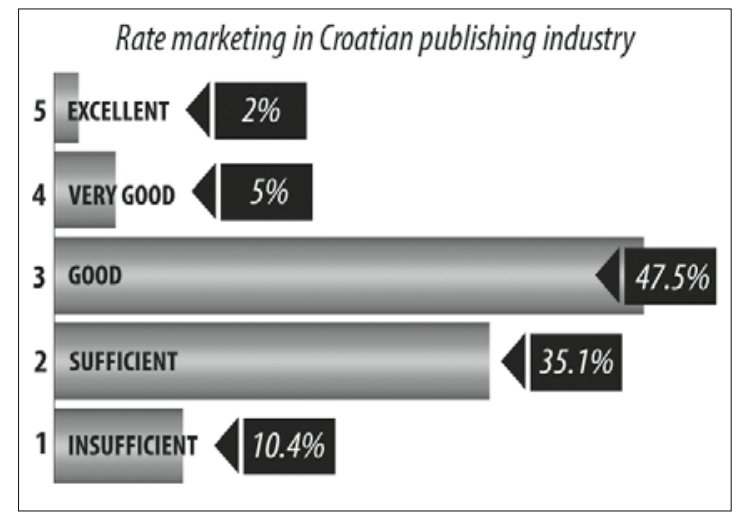

Figure 2. Marks for marketing in Croatia

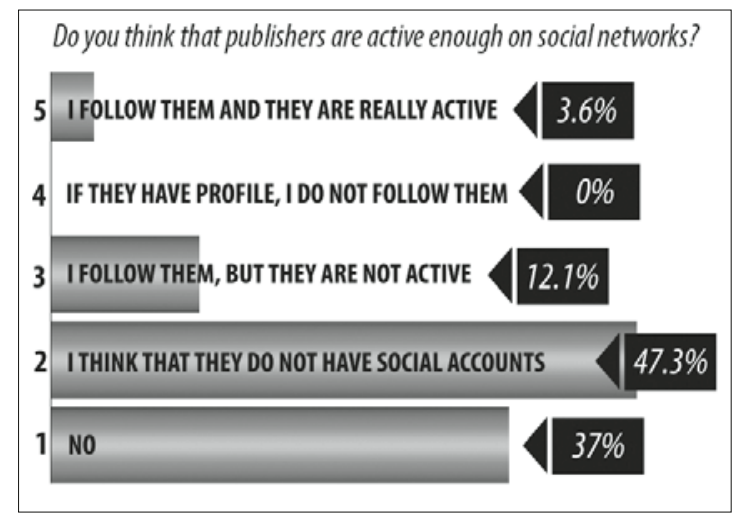

Figure 3. Publishers' activity on social networks
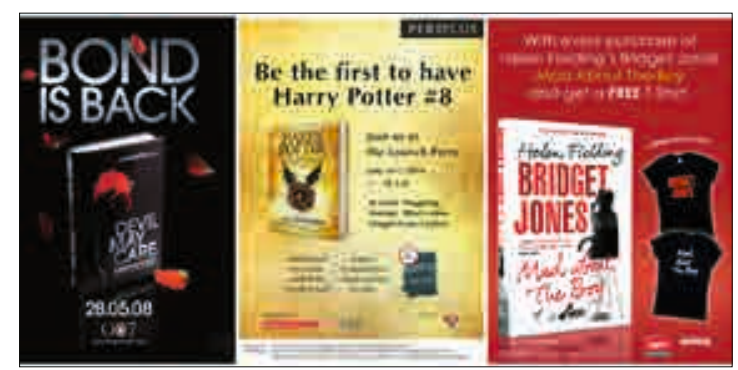

Figure 4. Examples of traditional ads - posters

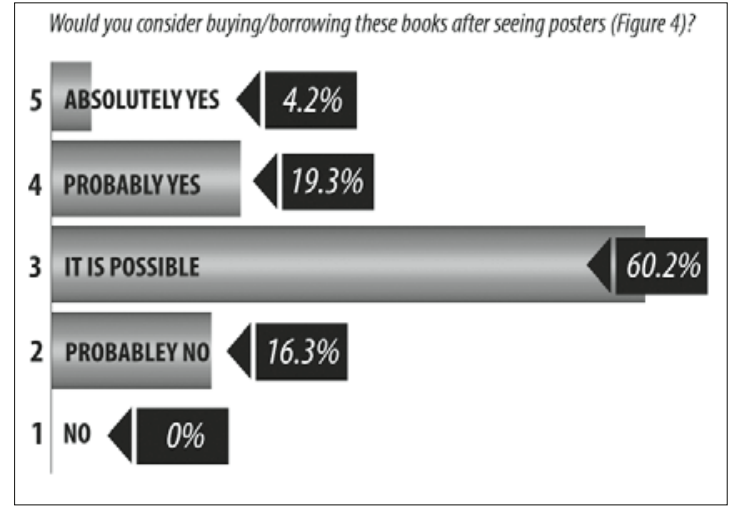

Figure 5. Relevance of traditional marketing in a form of a book poster

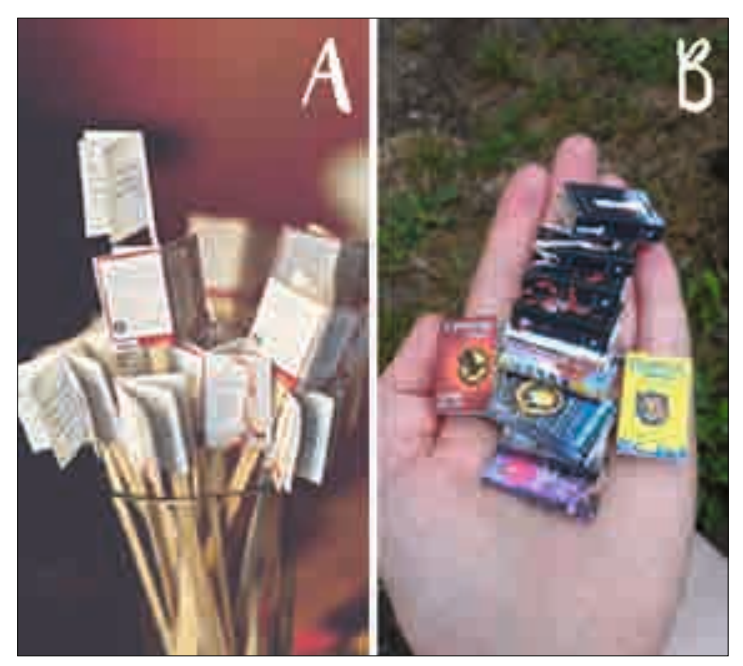

Figure 6. Hypothetical gifts (A - left \& B - right)

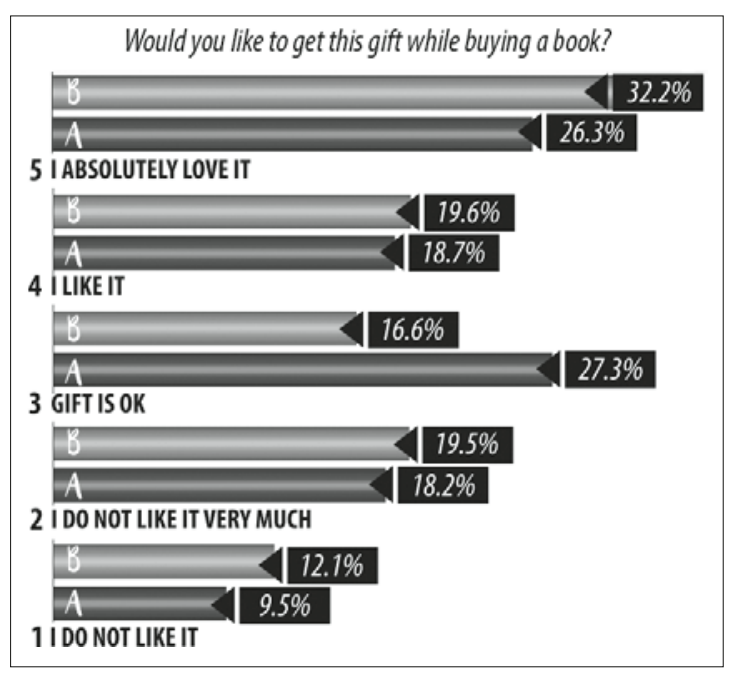

Figure 7. Example of sale improvement in marketing 


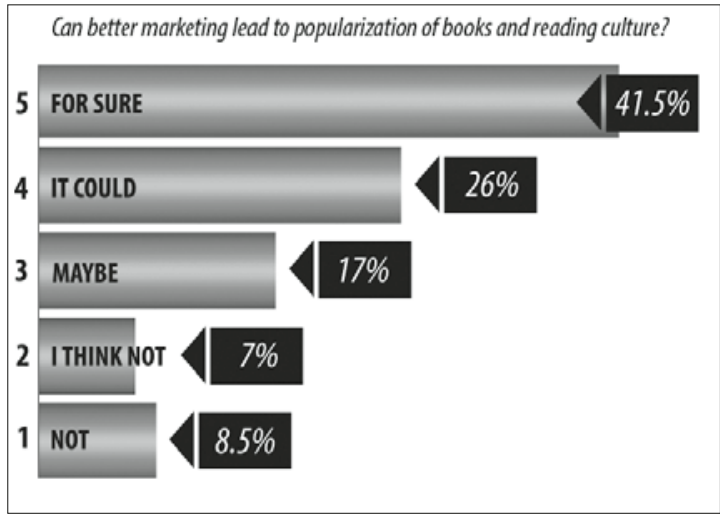

Figure 8. Opinion about correlation of marketing and reading culture

\section{Discussion of results}

The survey results, shown in Table 1, show that approximately $3 / 4$ of respondents read often (74.1\%), but only $37.3 \%$ read in English. Since they do not read books in English, which is the only language that can be found on Amazon (in general on similar web shops too); it is not surprising that only $6 \%$ of them is ordering books online. However, they like online book stores and more than $80 \%$ think that Croatia publishers need online library store. More than $3 / 4$ of respondents would read and buy more books in bookshops or online if more popular titles were translated in Croatian language.

In Figure 1, it is clear that outside and inside design of the book is powerful marketing tool. For $42.2 \%$ of respondents it is really important or important (mark 5 or 4). Well-designed book cover can be a great marketing tool itself. Many movies today are made after books, and using photo from a movie may boost profit. Certain design trends often occur, which are mainly related to the cover design and the choice of materials. Many people react positive on recycled paper [19]. Therefore, a lot of thinking and research must be done when designing a book to please customers and make book marketing much easier.

$45.5 \%$ of respondents rated marketing in Croatia publishing industry (Figure 2) as sufficient or insufficient (mark 2 or 1). In addition, almost $85 \%$ of them think that publishers are not active enough on social networks (Figure 3 ), which are one of the most important marketing tools today. More precisely, $47.3 \%$ think that publishers do not have social accounts and $37 \%$ that they are completely inactive.

In Figure 4 are three posters designed for book promotion, as example of traditional marketing tools. As it was mentioned earlier in this paper, traditional advertising and media are increasingly neglected. In Figure 5, results showed that only $16.3 \%$ respondents think that this kind of traditional advertising would not live an impact on them, and $23.5 \%$ are sure that they would borrow or buy these books after seeing the poster.

In Figure 5, there are two examples for hypothetical gifts with the book purchase (A gift - left, B gift - right). Both of these gifts are very creative and are good examples for sales improvement that was mentioned before, in Chapter 1. From arithmetic value (for both gifts together) it can be concluded that, $48.4 \%$ of respondents absolutely love or like these gifts and they would be thrilled to get them with a book purchase. Gift B was slightly more interesting to respondents than gift A.

Finally, $67.5 \%$ of respondents think that better marketing can lead to popularization of books and reading culture in Croatia. Actually, 41.5\% are sure and $26 \%$ think that it could. Book itself is a marketing tool. When selling a book, marketing experts sell a story, and behind that story is a feeling, so basically they are selling an illusion. However, everything today is about trends and fashion, and so are books. If publishing companies would do more marketing research and try to keep up with world trends that would have a positive impact on their profit.

\section{Conclusion}

Publishers do not know a lot about marketing possibilities, and the tools they know about they do not use at all or do not use properly. Social media is a big part of today's life style and some publishers just ignore it by not opening accounts, not being active or just having poor marketing. Result is that people do not know about their profiles or do not follow them. Also, their web pages and online book stores are badly managed and outdated, making it inconvenient to use. Furthermore, methods of traditional marketing are unduly forgotten. Flyers, posters, brochures, radio and TV commercials 
and other traditional marketing tools have a lot more possibilities, which have been neglected. Market analysis is not been carried out properly or at all, so not enough popular foreign books have been translated and not enough of world trends have been used. To summarize, publishers do not listen to their readers and that has led to a rapid fall in Croatian reading trend. Conducted survey has proven that younger reading population of Croatia is ready for the next step, ready for progress and ready for a sustainable profitable e-system. Moreover, they love hypothetical book promotion gifts and that leads to a conclusion that the crisis in publishing is not caused by the people, their interest, education or culture. Marketing has a lot of space for creative solutions without lot of investment that will certainly result with an increase in book sales. Nonetheless, education of employees, motivation and listening to the market is the right way to go. It is important to start progress by adopting simple things that have proven in practice, like putting less book titles in lower price promotions, to evolving and accepting bigger changes like print on demand, advancement of online book stores and dealing with the problem of distribution. Publishing might be an unprofitable industry that is slowly but certainly collapsing these days, but with a variety of option that modern marketing and advance in technology has to offer, it can heal, and the reading trend in Croatia can grow back again.

\section{References}

1. Escarpit R. Revolucija knjige. Zagreb: Prosvjeta; 1972.

2. Tomašević N. Kreativna industrija i nakladništvo. Zagreb: Naklada Ljevak; 2015.
3. Kraus T. Istraživanje tržišta knjiga u RH. Zagreb: GfK Hrvatska; 21.04.2017.

4. Cole D. The complete Guide to Book Marketing. New York: Allworth Press; 2003.

5. Thompson A.A, Strickland A.J., Gamble J. Strateški menadžment. Zagreb: Mate; 2008.

6. Kotler P., Keller K.L. Upravljanje marketingom. Zagreb: Mate; 2008.

7. Kotler P., Keller K.L. Marketing Management. New Jersey: Prentice Hall; 2012.

8. Chitty W., Barker N., Valos M., Shimp T.A. Integrated Marketing Communications. Melbourne: Cengage Learning Australia; 2011.

9. Sernovitz A. Word of Mouth Marketing. New York: Kaplan Publishing; 2009.

10. Calvin R.J. Kako stvoriti uspješnu prodaju. Zagreb: Masmedia; 2009.

11. Ferriss T. Četverosatni radni tjedan. Zagreb: Naklada Ljevak; 2009.

12. Blažević L. Moć marketinga u knjižnom nakladništvu. Zagreb: Naklada Jesenski i Turk; 2016.

13. Renko S. Distribucija i strategija distribucije. Zagreb: Sveučilište u Zagrebu, Ekonomski fakultet; 10.01.2017 cited date]. Available from: http://web.efzg.hr/dok/ TRG/6.nastavna\%20cjelina.pdf

14. World Record Academy. Fastest selling book - Harry Potter final book set world record. 11.01.2018. cited date]. Available from: http://m.worldrecordacademy.com/? url=http $\% 3 \mathrm{~A} \% 2 \mathrm{~F} \% 2 \mathrm{Fwww}$. worldrecordacademy.com $\% 2$ Fbusiness $\% 2$ Ffastest_selling_book_world_record_set_by_harry_potter_new_book_70663.htm\&utm_referrer=https\%3A\%2F\%2Fen.m.wikipedia.org\%2F\#2618

15. Anderson C. Dugi rep. Zagreb: Naklada Jesenski i Turk; 2008.

16. Clark G., Phillips A. Inside Book Publishing. Oxon: Routledge; 2008.

17. Dann S., Dann S. E-marketing: Theory and Application. Hampshire: Palgrave Macmillian; 2016.

18. Zhang Z.J., Raju J. Pametno određivanje cijena. Zagreb: Mate; 2011.

19. Ottman J. The New Rules of Green Marketing. San Francisco: Berrett-Koehler Publishers; 2011. 
This page was left blank intentionally! 